\title{
Multispecies curiosities and ethnographies
}

\author{
Paride Bollettin \\ Department of Anthropology, Faculty of Science, Masaryk University, Brno, Czech republic
}

Received $14^{\text {th }}$ October 2021; accepted $8^{\text {th }}$ December 2021

\section{VÍCEDRUHOVÉ ZAJÍMAVOSTI A ETNOGRAFIE}

\begin{abstract}
ABSTRAKT Př́spěvek popisuje vznik vícedruhové etnografie jako formy znásobení zkušeností a popisů za hranicemi lidského druhu. Navzdory tomu, že definice vícedruhovosti je poměrně nedávná, autor v článku tvrdí, že zájem o začlenění jiných než lidských bytostí do etnografického úsilí se datuje již od počátku disciplíny. Př́kladem tohoto zájmu je text The American Beaver and His Works (Americký bobr a jeho práce) napsaný roku 1868 Henrym Morganem, v němž autor tato zvířata účinně zařazuje do své etnografie. Článek pojednává o tom, že vícedruhový prŕstup může podpořit předefinování hlavních rysů etnografického výzkumu.
\end{abstract}

KLÍČOVÁ SLOVA Vícedruhovost, etnografie, zajímavost, hybridita, Morgan, bobři, nehumánní

ABSTRACT The paper describes the emergence of multispecies ethnography as a form of multiplying experiences and descriptions beyond the human. Despite the definition of multispecies being quite recent, the paper argues that the interest toward the inclusion of other-than-humans in the ethnographic effort dates back at the beginning of the discipline. An example of this interest is the text The American Beaver and His Works written in 1868 by Henry Morgan, in which the author effectively includes these animals in his ethnography. The thesis of the paper is that a multispecies approach can promote a redefinition of hybridity and curiosity as two core features of the ethnographic effort.

KEY WORDS Multispecies; ethnography; curiosity; hybridity; Morgan; beavers; other-than-humans

\section{INTRODUCTION}

Animals are present in everyday experiences, making unavoidable to taking them seriously in ethnographic efforts. In her work on animals' histories, Ravindranathan (2000) appoints how their presence turns such histories not only plausible, but also experienceable. Animals in histories present a "truly life", making them living narratives. Anyhow, being them the mythical Amerindian jaguars or the also mythical laboratories' rats, or even the domestic pets, these animals are nor trivial details, ornaments, allegories or metaphors in histories. They are subjects acting and producing real effects in direct experiences. In order to obtain this result, animals must be in the meanwhile over-determined, affected by what humans think to know about them, and under-determined, unrecognized so to become generic ones.

This ontological, epistemological and moral human indiscipline in front of animals highlights the necessity, or at least the utility, to include other beings with which the humans share the World in ethnographic experiences and descriptions. If "not everything is about us" (Tsing 2019, 144), so the ethnographic effort, being concomitantly "being in the field" and a "narrative about the field", become more effective and complete, more similar to our experiences, when it is able to include these other-than-human beings. From this starting point, in this paper I will discuss some implications of the inclusion of other-than-humans in the ethnographic effort, specially focusing on animals. To do this, I will begin with a description of ethnography as an anthropological specific practice, highlighting the inclusion of other-than-humans in its focus. In sequence, I will introduce a paradigmatic example of how other-than-humans have been crucial in the development of this peculiar form of being in and narrate the World. At the end, I will propose methodological consequences originated by this multispecies approach, underling hybridity and curiosity as key elements of the inclusion of other-than-humans in the ethnographic experience. The multispecies ethnography I wish to discuss here is related with the extension of the core 
focus of the living and describing a shared experience (core traits of "ethnography") beyond the frontiers of the "human", acknowledging its being merged in a network of companionships with other beings.

\section{ETHNOGRAPHY AND MULTISPECIES COLLECTIVES}

To discuss what "ethnography" could be is a hazardous task. As the old joke describes it: ask ten anthropologists what ethnography is, and you will have eleven answers. It would require so more space of what I have here, but the reader can find some insights in works that explore possible pathways in this direction (i.e. Bernard 2006; Okley 2020). What is important to remark is that such a difficulty originates from the diverse uses ethnographers do of this idea, focusing multiple elements concurring in defining a research practice. Widely defined, ethnography refers to the living and describing symbolic and practical experiences of the World, embodied and narrated, through a dialogue between the categories of the ethnographers and of their interlocutors. Certainly, this interest is not a novelty from anthropology, and various scholars appoint possible parallels with ancient thinkers and its not being a prerogative of the western-mediterranean-hegemonic World (i.e. Hyun Jin 2009). Despite these retrospectives, a certain hegemonic tradition recognizes in the works of authors such as Morgan (1922), with its focus on kinship systems among North American people, or Radcliffe-Brown (2013), with his attention on social organization of people from Andaman Islands, the foundation of a specific form of ethnographic experience and writing. In the hegemonic history of the discipline, the first scholar who emphasised the fieldwork as a specific feature of anthropology was Malinowski (1922). From then, only the experience of spending time "among the natives" (sic.) could offer appropriate knowledge of the language, participation in daily life, collection of histories and symbolic systems, etc.

These funding works of "modern" anthropology appoint toward an anthropology aimed at studying small scale societies, the ones they described as maintaining features of "traditional" social and cultural organization (i.e. Mead 2001). In this panorama, diverse approaches can be identified. Authors such as Malinowski (1922) highlight an idea of anthropology as a scientific endeavour, while others as a work closer to the literary production, such as Frazer (1987). Others suggest it to be an attempt to preserve a record of societies and their cultural expressions, seen as condemned to disappear (i.e. Benedict 1934). A common trait of these can be identified in the attempt to propose a wide comprehension of humanity. The more famous example of this anthropological holistic view maybe is the "four field anthropology", promoted by Boas (1904). He suggested the necessity to combine social anthropology, biological anthropology, linguistics and archaeology, in order to include its synchronic and diachronic dimensions. Despite this proposal had some influences on the following anthropological discussions, specially North American ones, various scholars suggest this effort does not pass of a myth (Borowski 2002).

In the following decades, various generations of scholars did not economize critics to these approaches, due to their focus on "other" societies as empirically exotic phenomena, compromising the ethnographers' authority to write about them (Taussig 1993). Anyhow, such critiques did not affect the principle of the "participant observation" as a fieldwork methodology. The influence of the ethnography as a direct and participant experience, as well as a way of narrating such experience, moved beyond the anthropological circle. Critics moved to the ethnographer's authority contributed in some way for ethnography as a method to transcend the study of "exotic" societies and also disciplinary frontiers. For example, Bateson (2006), in his study of Naven ritual among the Iatmul people, used diverse epistemological tools, including sociological, cognitive, and ethological approaches beyond the ethnographic one. His results anticipated several future discussions on the situated character of the explication, and he explicitly describes his effort as "a study on the nature of explication".

Since the second half of the Twentieth Century, a growing number of ethnographies focused understudied and invisibilized groups in anthropologists' societies. They began to do "fieldwork" in their cities, neighbourhoods, streets, redefining the qualification of the ethnographic practice, now focusing in making visible differences of power, interests and philosophies characterizing the social (Fisher 2003). Moving from the "exotic" societies and their colonial contexts, with implicit differences of power attributed to the producer of the ethnography (as both the "being there" and "writing about there") and its goal of holistic explanations, the ethnographic effort started to focus on interactions, participation, controversies, and conflicts affecting different collectives. If ethnographers were used to "pitching a tent in the native village" where remained for a year or more to access local life, when they shift their attention towards their own societies, observing their contradictions and fragmentations, also the relationships established with their interlocutors become more fragmented and fluid. In place of prolonged solitary stays, often unique, ethnography takes the form of a relationship that is more intermittent, but continued in time, more multiple, polyhedral and dynamic. This transformation, however, even with its epistemologically innovative character, still uses important methodological resources canonized by "classical" studies. Literary realism, interviews, historical documents, and other ways of constructing the ethnographic fact, continue to be used as instruments, but now inserted in a greater reflexivity on the role of the ethnographer as a researcher, writer and social actor.

Postcolonial debates, moving on this self-reflexive critique, firmly pointed out the need to democratize the ways of making ethnography, of being in the field, and of its narration. Such democratization highlights the urgency for research "objects" to be recognized as having a legitimate and symmetrical voice. The criticism of the classic ethnographic practice 
raised by authors such as Said (1978) was blunt in questioning the very possibility of making ethnography, which authority was for long time be grounded on a "having been in the field" legitimising its narrative. The symmetrization of voices in the field and in the narrative implied a radical redefinition of ethnographic practice. It claims that the "others", once objects of investigation, when they reappropriate of their voices not necessarily will interpret and communicate in the same way as the hegemonic perspective, with the consequence of a proliferation of the voices in the ethnography itself (Boswell - Nyamnjoh 2016). Questioning the statute of the ethnographer, whether in the field or as an exclusive narrator, opens the way to question ethnography (anthropology) itself as a scientific practice. If ethnographers' main tools are themselves and their sociability (Geertz 2000), the redefinition of the hitherto recognized ethnographic authority definitely stimulated the need to rethink ethnography's and anthropology's foundations.

These redefinitions of the dynamics and negotiations of "being in the field" and of its narrative, were moved by postcolonial deconstructions, the critical anthropology of the sixties and seventies, and also by the alternatives suggested by feminist theories. They also produced a strong anthropological reflection on the creative power of ethnographic language. Observing the power of writing in the articulation of cultural symbols, Geertz (1973) highlights its character as a builder of Worlds. Ethnographic writing, as a "thick description", is endowed with an evocative character that emphasizes the observer's presence. The reality of the "others" is described from the experience the ethnographer has of it. It is an experience, therefore, reflective and incorporated that, due to its very characteristic, requires a necessary reflection on its political implications. As evidenced by Van Maanen (2011), writing styles can produce alternative ethnographic realities: a realistic style will produce a direct picture of the situation regardless of how the ethnographer has produced his data, a confessional style will highlight the work of the ethnographer more than the research itself, an impressionist style will involve the reader in an ethnographic dramatization, and so on. This "linguistic" turn of anthropology, focusing on ethnography as the production of a narrative, emphasizes that both the experience and its representations are "emergent" (Clifford 1986). This vision of ethnography as focused on the creative power of the narrative, on the one hand shifts the focus of ethnography from the "reality" of cultures to their polyphonic creation, thus allowing the inclusion of multiple, not necessarily coherent, voices in the enterprise. On the other hand, however, as some critics have pointed out, it poses the danger that this emphasis on language as a producer of the ethnographic world could melt the boundaries between ethnography and fiction, consequently weakening its effectiveness in contesting the structures of power that make specific social groups invisible.

In an attempt to bring together in the same ethnography people and objects, the observer and the observed, some anthropologists have turned their attention to the reciprocal co-production of the language and its referents. This co-production is grounded on the "practices" within which the multiple actors interact. Moving beyond the idea that ethnographic "reality" would reflect an objective "truth", ethnographies should focus on making visible the processes through which "reality" becomes "truth" for the involved actors. From the "truth", then, to the "map" of the relationships connecting natural and social worlds, since social forces themselves would not have an independent existence outside the concrete combination and interaction of concomitant heterogeneous elements. For example, Latour (2005) suggests that ethnography should "describe" the movements and relationships between material and semiotic actors, people and discourses, and not "explain" them, since they act as a whole, being not possible to split them into separate epistemological dimensions. This suggestion echoes Bateson (2006 [1936, 1958]), according to whom the "organization" of data is their "explanation", which derives precisely from the possibility of joining heterogeneous elements within patterns that enable to map their connections. The experiences and interactions throughout the ethnography must, therefore, be observed in their own making, in what connects the most diverse elements: "What people say in an interview doesn't only reveals their perspective, but also tells about events that they lived through" (Mol 2002, 15). The proposal of this ethnographic perspective is to follow the multiple elements in their multiple movements, through a meticulous mapping of their relationships.

This approach to ethnography, sometimes defined as post-human, because it included both humans and other-than-humans in its analysis, stimulated a comprehensive effort aimed at bringing together the most different elements producing lived experiences. Making the ethnography of these experiences, therefore, requires moving beyond the human, including other beings, such as microbes, artificial intelligence, animals, etc. The proposal is to avoid the "hyper-humanism" that characterized field practices and their narratives (Smart 2014). The anthropocentric emphasis, in this view, would have obliterated the relations connecting humans with other beings. Ethnographers, here, emerge "not only as researchers, world-makers, text-creators and so on but also as members of a researching species" (Hamilton - Taylor 2017, 44). In this way, the inclusion of other-than-humans in ethnography wish to promote epistemological, ontological and moral alternatives toward an "anthropology beyond the human" (Ingold 2013). The multispecies ethnography proposal goes in this direction, and proposes to map cultural, political and social influences affecting the relations between diverse beings (Kirskey - Helmreich, 2010). This possibility has significant ecological, political and moral consequences, as emphasized by the search for alternatives for coexistence between humans and other-than-humans in the face of environmental crises generated by anthropocentric capitalism (Tsing 2015). Methodologically, this approach aims at moving the ethnography toward other ways of "being", not only those that the hegemonic ontology considers as "alive", such as the animals, but also those it considers as "inanimate", such as minerals and objects, as well as those refused by hegemonic ontologies, such as spirits, 
for example. This does not mean to neglect the "human" as the focus of ethnography, after all anthropology is about the "anthropos", but rather to map its expanded relations (Lien Pálsson 2019).

This brief overview, partial and incomplete, aimed at introducing the polysemy of ethnography, which can take diverse and even contradictory connotations. Here I chose some trajectories more coherent with the objectives of this text, although many other "(hi)stories" of ethnography could be traced. I would like to introduce now a specific ethnographic case of multispecies ethnography: a book published in 1868 by Lewis Henry Morgan, already mentioned above, and considered one of the funders of the hegemonic anthropological tradition.

\section{THE AMERICAN BEAVER}

Lewis Henry Morgan is mostly known among anthropologists for his work on kinship systems $(1997,1922)$, a field of research of which he is considered one of the founders. Indeed, Lévi-Strauss dedicated to him his first mayor work (1967), recognizing how Morgan anticipated the primacy of kinship relations that connect individuals in the face of the study of classificatory terms (Almeida 2010). Despite usually described as a "cabinet anthropologist", like most of his contemporaries who adhered to social evolutionary theories, Morgan can also be considered a precursor of the fieldwork as it came to be configured in the following decades. The data on which he grounded his works on kinship were largely collected personally or under the direct guidance of Native Americans interlocutors, through questionnaires and through direct dialogues with them. He had this possibility since he spent several years of his life working as an employee of the Ely railway and mining company in the surroundings of the Great Lake, a region inhabited by the Native Americans and, as we shall see, by the beavers.

Less well known are his works on American beavers, the most remembered of which is the book The American Beaver and His Works (1868), which is also mentioned by Darwin (2004). His core point is that "the mute [sic.] and man [sic.] are both endowed with similar mental principle" (Morgan 1868, 250). This affirmation significantly distanced him from his contemporaries, who saw compared animal anatomy as the foundations of zoological science (Idem.: v). Morgan, defining his enterprise as an "experiment", aims to carry out "a minute exposition of theirs [of the beavers'] artificial works, where such are constructed; of their habits, their mode of life, and of their mutual relations" (Idem.: vi). A specific "ethnographic" view, at the same time method and object for Morgan, appears clearly from the opening pages. The expression "where such" highlights that Morgan observe the beavers in situ, something that ethology will only begin to accomplish in the sixties of the following century with the "pioneering" works of Konrad Lorenz and Niko Timbergen (Souto 2005). Furthermore, the autobiographical notes that Morgan inserts in his narrative situate the ethnographer himself in his field context, thus anti- cipating the self-reflective attention to biosocial relationships that some ethnographies emphasise today (Lien - Pálsson 2019).

Although he wrote his works on the beavers and the human kinship systems in the same period, his readers maintained them separated. The former are revered among zoologists as a precursors to studies of animal behaviour, and the latter among anthropologists as the first "modern" studies of kinship. A parallel between these studies can be found in the fact that Morgan assumes "the mute and the man" as having the common characteristic of conscious beings, often associating them due to their social characteristics and industrious attitudes. He had already expressed this idea in a previous work, arguing that humans and animals share cognitive, communicative, sensory and rational abilities. "The strong and uninterrupted current of analogies in animal life, also, which subsist between man [sic.] and the various species of animals, furnished an indirect support to the views hitherto advance. They have the senses, natural affections, and propensities, in common with man" (Morgan 1843, 419).

However, the intellectual environment in which his work is inserted was still discussing slavery and physical differences between humans, so that the multiple associations with the beavers were distorted to distinguish the humans themselves. The details of these associations allow Morgan to uncover tensions and contradictions embedded in this ambiguous operation of association between beavers and humans, anticipating later debates. The recognition of the intellectual uniqueness of humans and beavers was a clear attack to the widespread racism in North American society at the time (and not only, i.e. Rana 2020), as it refuted the possibility of qualitative human diversities. Consequently, in this, it is possible to recognize a double movement of trans-specific universality of both kinship systems and "intelligence".

Morgan's attention to the beavers' engineering works expresses his focus on detailing what these animals were doing in "practice". This is further evidenced by the also pioneering use of images as ethnographic documents: the book uses numerous drawings to illustrate descriptions of the beavers' works and their lives. The author described how he had cut the dikes built by these rodents in order to detail their structures. He spent years in a patient effort to directly observe the beavers at work, something made difficult by their nocturnal habits. Observing what the beavers do acquires in Morgan a methodological and epistemological dimension for understanding their behaviours: "their artificial erections speak for themselves, their habits, in other respects, can only be determined by a series of authenticated acts" $(1868,133)$. Here he anticipated debates that will emerge more than a century later. For example, Haraway, in examining the value policies produced by the co-adaptation of humans and animals, draws attention to the nature of "living capital" of the latter: "My suspicion is that we might nurture responsibility with and for other animals by plumbing the category of labour more than the category of rights" $(2008,73)$. In Morgan's description, beavers build numerous dikes in the area occupied by human villages, where 
he tells: "There are within this area sixty-three beaver dams, without reckoning the smallest, from those which are fifty feet in length, and forming ponds coving a quarter of an acre of land, to those which are three hundred and five hundred feet in length, with ponds covering from twenty to sixty acres of land. It also contains many acres of beaver meadows, many lodges, burrows, and artificial canals" (Morgan 1868, 80). Beavers' working skills are associated on the one hand with the recognition of the "intelligence" of these animals, thus associating them with humans, and on the other hand, as we have seen, with the direct observation of what they do in the practice. This preoccupation, however, is also connected with the devastating expansion of the American "frontier" over the region, so expressing a preoccupation that is not only epistemological, but also moral.

The advance of this frontier, at offering the beavers' engineering works to the colonizers' view, impacted their coexistence with the local Native populations. Morgan is explicit in acknowledging his debt for carrying out his study with them and with the fur hunters in the region: "After considerable intercourse with Indian and white trappers [...] I have been, through them, to verify but a small number of facts tending to establish, as well as to illustrate, the habits and mode of life of this long-observed rodent" (Idem., 133). This coexistence of the beavers with the humans was, however, marked by their exploitation from intensive hunting for their skins, which was carried out using specific traps. One of these, the Newhouse Trap (used by "white" hunters), is described by Morgan as "the most perfect instrument" (Idem., 229). Hunting, associated with their nocturnal habits, made them even more difficult to observe. Morgan looked for the help of the more experienced people, especially the Objiwa and the sons of interethnic marriages and to whom he explicitly recognizes his debt "for the acquaintance with the "beaver love' of the Indians" (Idem., xi). Even though it is not a direct reflection on the co-authorship of the fieldwork, and it could not be due to the particular socio-historical period in which the text was written, this recognition describes a humility of the ethnographer concerned with respecting his local interlocutors, crediting them their own knowledge. It is a discussion that would have emerged as a priority in ethnography only decades later. This debt becomes more evident when Morgan recognizes, in other texts on the subject (1843), that the attention toward the work of the beavers was raised by the local perception of these works as "signs". The attention that local residents paid to the structures built by these animals was derived from the fact that they were living in the same territory, and therefore experiencing each other directly. Their willingness to show the beavers to Morgan went together with explanations of the animals' social life. The social life of the beavers, consequently, from the Native Americans' explanations included in the work Morgan, cannot be divided from their buildings. In this sense, it is possible to relieve that a local explanation anticipates something that the ethological studies of beavers will recognize in more contemporary times (Wohl 2019). Moreover, the attention to multi-species social life and its connection with the territory motivated local residents to be concerned that human impacts could lead to the disappearance of the beavers. A concern shared by Morgan himself, who was aware of the contradiction in which he was immersed because he was in the region as an employee of the mining and railway company responsible for the destruction of the local ecosystem and, consequently, for the disappearance of the beavers' populations. This brief description of Morgan's work on American beavers illustrates some interesting features of his ethnographic work. In a comprehensive view, Morgan addresses various topics, such as the beavers' anatomy and feeding, their engineering works in the manufacture of dikes, and their social life, but also the techniques of hunting these rodents and their other interrelationships with the humans living in the territory. Possible critiques to Morgan's "ontological" proposal about the intentionality of beavers, have raised questions about a supposed confusion he would have made between the double levels of "knowing how to do something" and "having an idea of something", the latter taken as a properly human characteristic (Ingold 1987, 29). Anyhow, it is relevant to point out how The American Beaver and His Works anticipates numerous themes that will emerge in the debate decades after him. Specifically, this is evident for the ones produced in the discussion of multispecies collectives and the post-human anthropology. In the next paragraph, I will outline some of these suggestions for the discussions of ethnography.

\section{NOTES ON MULTISPECIES ETHNOGRAPHY}

This brief overview of Morgan's text, in some way neglected in the "anthropological canon", leads us to question what happens to the ethnographic method when ethnographers turn their attention to other-than-humans. That is, to the impacts these other-than-humans have on the ethnographic experience. This question is grounded on the perception that "Others really are" (Hamilton and Taylor 2017, 51). It was inevitable, for example, that Morgan's attention to beavers would be heightened by their pervasive presence in his experience of the place. Their "reality", however, was highlighted by the explicit association Native Americans made with the human sociality, or, to put it another way, the beavers were, in the direct experience of the locals and of Morgan, "good to live with" (Haraway 2008). Instead of observing them from a reductionist, utilitarian or symbolic perspective, Morgan focuses his ethnographic attention on them as co-participants in the realization of the experience. It is a movement that is intrinsic and concomitant epistemological and methodological, as well as moral, of course.

Returning to the usefulness of focusing ethnographic attention on what subjects "do", it can be observed that in order to map other-than-human agencies a good starting point is the way in which such agencies are incorporated in well-specified social contexts. Power differences in the relationship between humans and other animals, for example, are made explicit in everyday practices that reflect cultural norms. The difference 
between companion animals that are taken for walks and fed selected foods, etc., and their conspecific mutts, who receive blows and are imprisoned in shelters, etc., makes evident how interspecific boundaries take on moral values rather than "biological" ones. It is useful for the ethnographer to observe what the pair formed by a dog and its "owner" do while walking along the city's streets, for example, on their more or less fast or slow walking, or using the collar to pull or if he lets himself be pulled or engaged in direct or indirect conversations (conducted by anyone who lives with a domestic animal). In this way the ethnographer maps out the emergence of an affectivity that shapes interspecific communication. Such affectivity echoes the crossing of borders that divide humans from their "others", a movement that acquires specific forms and modalities in each multispecies context and collective.

The observation of these practices thus emerges as crucial for accessing the ways in which multispecies collectives display their dynamics, allowing the common participation of different agents in the production of lived worlds to be made explicit. From this perspective, however, it is also the object of anthropology that undergoes a redefinition. Other-than-humans, especially animals, but also plants and invisible beings, despite diverse presences in ethnographies (Smart 2014), have always been present in ethnographic research since they are present in the very experience of collectives with which the ethnographer lives. However, in most cases, other-than-humans presence in ethnographies is shaped by an approach that defines them as "instruments" both of the "natives", as in the case of the ritualistic bears described by Benedict (1934), or of the ethnographers themselves, as in the case of the Geertz's roosters as metonymic of Balinese masculinity (1973). The proposal of a multispecies ethnography aims, on the other hand, to achieve a more detailed description of social groups, avoiding to "imagine human species being, that is, the practices of being a species, as autonomously self-maintaining" (Tsing 2012, 144). The recognition that the "human species being" is not a self-sustained attribute, but something under construction in interspecific relationships, allows to focus the flows of relationships materialized in particular bodies and practices ethnographers find in their experiences.

Dynamics shaping these interspecific relationships can be accessed by observing the trajectories of beings engaged in ethnographies: "any thing - caught at a particular place and moment - enfolds within its constitution the history of relations that have brought it there" (Ingold 2011, 160). What specific bodies of other-than-humans do in their practices allows, therefore, to elucidate their countless relationships. In Morgan's work, this is evident: the beavers are presented at a given historical moment, along the rivers, with their dikes and with their families, describing their specific intervention in the process of landscape formation. Their absence, after a few years, will, in turn, allow the ethnographer to access the new relationships involving these animals, this time with mining companies, with fur hunters, etc. At the same time, these presences "at a particular place and moment", as an epiphenomenon of more comprehensive practices involving multiple humans and other-than-humans, also allow to access the epistemological and methodological practices operated by the "other" human observers in their multispecies collectives. In the production of scientific in laboratory practices, for example, other-than-humans are obliterated in the narrative (Latour - Woolgar 1986). But the same happens also outside the laboratory space, such as in the act of hiding the personal and affective relationships between human and other-than-human primates in primatological research both in captivity (Wieder 1980) and in "nature" (Sá 2013; Bollettin 2020a, 2020b).

This suppression of the links between humans and other-than-humans is not a prerogative of scientific descriptions, but rather the common feature of a general anthropocentric approach that excludes other-than-humans by not recognizing their specific agencies. The emancipation of these in ethnography cannot be, however, the simple observation of how humans define themselves or build themselves in opposition to the silenced "others". Given that interspecific experiences engage these collectives in shared Worlds, the ethnography requires an effective symmetrisation, redefining the discourses that exclude those with less speech power from the decision-making process precisely because they suffer of such silencing (Stenger 2005). A redefinition that implies, following Stenger's suggestion, to make evident inclusion and exclusion policies, as well as the ethnographer's moral, epistemological and methodological choices. In this direction, two practical and narrative strategies used in multispecies ethnography appear as relevant: hybridization and curiosity.

As The American Beaver and His Works evidence, the anthropological enterprise was not entirely anthropocentric at its foundation. In the course of time, the exclusive focus on the "human" gained, nevertheless, an absolute preponderance, due to factors internal and external to disciplinary interests, promoting an increasing disciplinary specialization (Cardoso de Oliveira 2006). The effort to "take other-than-humans seriously" in ethnography thus requires a parallel effort to rethink the epistemological and methodological limits of ethnography itself. Several disciplines, for example, focus on human-animal relationships (which can be expanded to include other beings, such as plants and spirits, for example), so that an effective and efficient inclusion of other-than-humans in ethnography can greatly benefit of a disciplinary "hybridization" (Hamilton - Taylor 2017). Hybridization that, again, is both epistemological and methodological. On the one hand, it requires to establish dialogues between different approaches, such as the ones that can be held between anthropology and primatology around the multiple meanings of the term "culture" beyond the usual attribution to humans, which can lead to reformulate the categories of beings we recognize and their borders (Rapchan - Neves 2014). On the other hand, it runs towards relationships escaping scientific-academic borders, implying a redefinition of paradigms hitherto accepted from the inclusion of the different perspectives of those who participate in these relationships, trying to identify their possible partial overlaps (Ludwig - El-Hani 2020). This operation can already be identified in Morgan's text in which 
the author makes extensive use of both Ojbïwa terminology and categories. Not only the local linguistic terms enter the ethnographer's text, but also Native Americans' concepts shape the author's epistemology, as clearly appears, for example, in the use of the idea of "family" to describe the beavers' territorial occupation.

Meanwhile, this hybridization extends the possibilities of ethnographic methods in the production of poly-vocal, creative and multiple ethnographies. To the more "traditional" diaries, notes, interviews, etc., several authors have suggested adding the use of videos, artworks, and other experimentations in multiple directions (Kirskey, 2014; Hamilton - Taylor, 2017). Although the use of these expressive forms in ethnography, both in the field and in the narrative, does not necessarily mean that other-than-human voices are heard, these instruments have the utility of "talking with" them (Haraway 2008). The use of alternative forms of dialogue in the ethnography can engage interlocutors in the use of visual forms of presentation of their experiences, offering instruments that complement the narrative (Pauwels 2016). In addition to using images to illustrate the ethnographic narrative, as in Morgan's book, these instruments open spaces for the proliferation of multiple voices. These voices are expressions of the variety of both human interlocutors engaged in multispecies collectives, and of other-than-human beings themselves. The video Sweetgrass (Castaing-Taylor - Barbash 2009), for example, rethinks ethnographic research on grazing, but shifting the gaze to the multispecies collective itself: the sounds and images of shepherds, horses, dogs and sheep intertwining. At the same time, hybrid forms of presentation of these collectives, such as those presented in The Multispecies Saloon (Kirskey 2014), allow to bring to light their multiple dynamics, transgressing the epistemic-ontological boundaries that separate humans and other-than-humans and exploring original ways of bringing together bacteria, eggs, flowers, humans, etc. These tools produce a common panorama that is at the same time a lived world, a polyphonic narrative and a political manifesto.

Some of these epistemic-methodological possibilities opened by a multispecies approach in ethnography show that experimentation is an intrinsic characteristic of the attempt to make it inclusive. On the one hand, this is the result of the multiplication of the beings involved, since each of these will have their own ways of staying in and narrating the multispecies collectives. On the other hand, it is also the result of an appreciation of curiosity as a particular methodological instrument. Curiosity understood as a desire to know is nothing new in anthropology: Karl Kroeber, son of Alfred Kroeber, uses this keyword to describe his father's anthropological undertaking (Kroeber 2003). However, the "Kroeberian" curiosity is thought of as an egoistic curiosity of the ethnographer himself and can be thought of in association with a posture that exoticizes the "other", that is, a curiosity that objectifies the other. This form of the ethnographic curiosity, which even supported the colonial expansion (Taussig 1993), is reflected in the projection of the ethnographer's interests on the reality of the "natives" he seeks to study (Crapanzano 1986).
In another direction, curiosity can be experienced as "expansive": "whom and what do I touch when I touch my dog?" asks Donna Haraway $(2008,3)$. This other approach to curiosity emphasizes its potential to allow oneself to be "contaminated" - or, again, hybridized - by the differences arising in the interspecific encounter, in a movement of "learning to be affected" (Latour 2004). Recognizing the agency of other-than-humans in our experience of the world, whether they are the beavers described by Morgan, domestic pets or laboratory rats, etc., lets to expand ethnography beyond anthropocentric borders and pre-given questions. This redefinition of curiosity, in the same direction as postcolonial criticism that reformulated ethnographic dynamics in a dialogical perspective between the involved subjects, aims at including other curiosities in such multispecies collectives. It is a process of inclusion of others that were once neglected: "Multispecies anthropology makes much-needed interventions by positing curiosity and noticing as antidotes to blindness about nonhumans" (Swansson 2020, 33). It displaces the curiosity "about" to the curiosity "with". The conjunction "with", however, is not only epistemological and methodological, but it implies assuming a moral stance, full of new obligations and responsibilities (Tsing 2013).

\section{AS AN OPEN CONCLUSION: MOVING FORWARD THE MULTISPECIES ETHNOGRAPHY PROPOSAL}

The current ecological crisis that devastates (or will devastate, in the most optimistic view), the planet, makes it urgent to rethink the interaction dynamics between humans and other-than-humans. The ongoing Coronavirus pandemic has its origins in a zoonosis (Jo et al. 2020). The reformulation of the relationship between humans and wild animals, in this case probably between humans and bats, produced by the degradation of their ecosystem, brings humans and other-than-humans together in an uncontrolled way, generating unpredictable and disastrous effects for humans themselves. Multispecies ethnography suggests rethinking the dynamics that humans adopt in multispecies collectives, in an ethnographic and political claim. Along this paper, I have presented only a few suggestions, but which represent a panorama so varied that any definition ends up being ironically reductive of its own effort of multiplying possibilities. It is not only a simple intellectual curiosity, toward the understanding of the workings, controversies, dynamics, conflicts and appeasements of these collectives, it suggests that an ethnography capable of including other-than-humans in its dialogues appears as an effective epistemological and moral position facing current environmental crises. This position, however, as the choice of the text The American Beaver and His Works suggests, is not new. In his book, Morgan shows us, with the epistemic, ontological and moral categories of his time, the cosmopolitical potential of ethnography: the observer, the humans, and the beavers are symmetrized in a plural narrative that redefines the prevailing hegemonic borders. 
If ethnographic practice served as an instrument of colonial domination (Taussig 1993), it also offered clues to propositional movements capable of altering the play of forces in more plural directions (Said 1978). The explosive potential of ethnography as a methodology, engaged and polyhedral, eccentric and pluralistic, thus offers an instrument for an effective commitment with the lives of other-than-human companions. The movements of disciplinary, epistemological and moral hybridizations and the redirection of ethnographic curiosity towards a curiosity "with" others, appear, therefore, as peculiar traits of an ethnography that seeks not only to include the other-than-humans in its sphere of interest, but that above all allows itself to be moved toward the directions they suggest. It is not only related with the inclusion of an additional "object" of research, instead it suggests to rethink ethnographic knowledge-practices toward the recognition of plural Worlds, letting other-than-humans to symmetrically engage in a dialogical effort which is concomitantly onto-epistemological as well as ethical. Such an extension promotes the proliferation of possibilities, being "taking seriously" (Viveiros de Castro 1998), meaning to have as a starting point the question of how other experiences enable to rethink the subjective experiences of the observer as relative and situated, the ground on which build up future subjective relations between humans and other-than-humans.

\section{REFERENCES}

Bateson, Gregory $(2006[1936,1958])$ : Naven: a survey of the problems suggested by a composite picture of the culture of a New Guinea tribe drawn from three points of view. Stanford: Stanford University Press.

Benedict, Ruth (1934): Patterns of culture. New York: Houghton Mifflin Harcourt.

Bernard, Russell H. (2006): Research Methods in Anthropology: Qualitative and Quantitative Approaches. Lanham: Altamira Press.

Bollettin, Paride (2020a): Wilderness and domestication in human-other-than-human primate collectives. Áltera, 3(11), 201-226.

Bollettin, Paride (2020b): Quem é um primata? Etnografias de primatas entre primatólogos e Ameríndios. Habitus 18(2), 539-561.

Borowsky, Robert (2002): The Four Subfields: Anthropologists as Mythmakers. American Anthropologist, 104(2), 463-480.

Boswell, Rosabelle and Nyamnjoh, Francis (2016): Postcolonial African Anthropologies. Cape Town: HSRC Press.

Cardoso de Oliveira, Roberto (2006): Antropologia e interdisciplinaridade. In Eckert, Cornelia and Godoi, Emilia Pietrafesa, eds., Homenagens. Associação Brasileira de Antropologia 50 anos. Florianópolis: Nova Letra, $51-56$.

Castaing-Taylor, Lucien and Barbash, Ilisa (2009): Sweetgrass. Cinema Guild, 109 mins, USA.

Clifford, James (1986): Partial truths: Introduction. In: Clifford, James - Marcus, George, eds., Writing culture: The politics and poetics of ethnography. Berkeley: University of California Press, 01-26.

Crapanzano Vincent (1986): Hermes' Dilemma: The Masking of Subversion in Eth- nographic Description. In Clifford, James - Marcus, George, eds., Writing Culture: The Poetics and Politics of Ethnography. Berkeley: University of California Press, 51-76.

Fischer, Michael (2003): Emergent forms of life and the anthropological voice. London: Duke University Press.

Frazer, James George Sir (1987 [1890]): The golden bough: A study in comparative religion. London: Vantage Press.

Geertz, Clifford (1973): The interpretation of cultures: Selected essays. New York: Basic Books.
Geertz, Clifford (2000): Available light. Anthropological reflections on philosophical topics. Princeton: Princeton University Press.

Hamilton, Lindsay - Taylor, Nik (2017): Ethnography after Humanism: Power, Politics and Method in Multispecies Research. London: Palgrave MacMillan.

Haraway, Donna (2008): When Species Meet. Minneapolis: University of Minnesota Press.

Hyun Jin, Kim (2009): Ethnicity and foreigners in ancient Greece and China. London: Duckworth.

Ingold, Tim (1987): The appropriation of nature: Essays on human ecology and social relations. Iowa City: University of Iowa Press.

Ingold, Tim (2011): Being Alive: Essays on Movement, Knowledge and Description. London: Routledge.

Ingold, Tim (2013): Anthropology beyond humanity. Suomen Antropologi: Journal of the Finnish Anthropological Society, 38(3), 05-23.

Jo, Wendy; Oliveira-Filho, Edmilson Ferreira; Rasche, Andrea et al. (2020): Potential zoonotic sources of SARS-CoV-2 infections. Transboundary and Emerging Diseases, DOI: 10.1111/tbed.13872

Kirskey, Eben, ed. (2014); The multispecies salon. Durham, NC: Duke University Press.

Kirskey, Eben - Helmreich, Stefan (2010): The Emergence of Multispecies Ethnography. Cultural Anthropology, 25(4), 545-576.

Kroeber, Karl (2003): Curious Profession: Alfred Kroeber and Anthropological History. Boundary 30(3), 144-155.

Latour, Bruno (2004): How to Talk About the Body? The Normative Dimension of Science Studies. Body \& Society, 10(2-3), 205-229.

Latour, Bruno (2005): Reassembling the Social: An Introduction to Actor-Network Theory. Oxford: Oxford University Press.

Latour, Bruno - Woolgar, Steve (1986). Laboratory Life. Princeton: Princeton University Press.

Lien, Marianne E. - Palsson, Gisli (2019): Ethnography Beyond the Human: The 'Other-than-Human' in Ethnographic Work. Ethnos, 01-20, DOI: $10.1080 / 00141844.2019 .1628796$

Ludwig, David - El-Hani, Cahrbel (2020): Philosophy of Ethnobiology: Understanding Knowledge Integration and Its Limitations. Journal of Ethnobiology, 40(1), 03-20.

Malinowski, Bronislaw (1922): Argonauts of the Western Pacific: An account of native enterprise and adventures in the Archipelagos of Melanesian New Guinea. London: Routledge and Kegan Paul.

Mead, Margaret (2001 [1949]): Male and female. New York: Harper Perennial.

Mol, Annemarie (2002): The body multiple: Ontology in medical prcatice. Durham: Duke University Press.

Morgan, Lewis Henry (1843): Mind or Instinct. An Inquiry Concerning the Manifestation of Mind by the Lower Orders of Animals. The Knickerbocker, 22(11), 414-420; (12), 507-515.

Morgan, Lewis Henry (1868): The American Beaver and His Works. Philadelphia: J.B. Lippincott.

Morgan, Lewis Henry (1997 [1871]): Systems of Consanguinity and Affinity in the Human Family. Lincoln e Londres: The University of Nebraska Press.

Morgan, Lewis Henry (1922 [1904]): League of the Ho-Dé-No-Sau-Nee Or Iroquois. New York: Dodd, Mead and Company. https://archive.org/details/hodenosaunee00morgrich. Downloaded on 6th October 2021.

Okely, Judith (2020): Anthropological Practice: Fieldwork and the ethnographic method. Oxon: Routledge.

Pauwels Luc (2016): 'Participatory' visual research revisited: A critical-constructive assessment of epistemological, methodological and social activist tenets. Ethnography 16(1), 95-117.

Radcliffe-Brown, Alfred Reginald (2013 [1922]): The Andaman islanders: A study in social anthropology. Cambridge: Cambridge University Press.

Rana, Junaid (2020): Anthropology and the Riddle of White Supremacy. American Anthropologist 122(1), 99-111.

Rapchan, Eliane Sebeika - Neves, Walter (2014). Primatologia, culturas não humanas e novas alteridades. Scientee Studia, 12(2), 309-329.

Ravindranathan, Thangam (2020): Behold an Animal: Four Exorbitant Readings. Evanston: Northwestern University.

Sá, Guilherme (2013): No mesmo galho: antropologia de coletivos humanos e animais. Rio de Janeiro: 7Letras.

Said, Edward (1978): Orientalism. London: Routledge.

Smart, Alan (2014): Critical perspectives on multispecies ethnography. Critique of Anthropology, 34(1), 03-07. 
Souto, Antonio (2005): Etologia: Principios e Reflexões. Recife: Editora da Universidade Federal do Pernambuco.

Stenger, Isabelle (2005): The cosmopolitical proposal. In: Latour, Bruno - Weibel, Peter, eds., Making things public: Atmospheres of democracy. Cambridge: MIT Press, 994-1004.

Swansson, Heather Anne (2020): Curious ecologies of knowledge: more-than-human anthropology. In Zurn, Perry - Shankar, Arjun, eds., Curiosity Studies: A new ecology of knowledge. Minneapolis, University of Minnesota Press, 15-36.

Taussig, Michael (1993): Mimesis and Alterity: A Particular History of the Senses. New York: Routledge.

Tsing, Anna (2012): Unruly Edges: Mushrooms as Companion Species. Environmental Humanities, 1(1), 141-154.

Tsing, Anna (2013): More-Than-Human Sociality: A Call for Critical Description. In Hastrup, Kirsten, ed., Anthropology and Nature. New York: Routledge, 27-42.

Tsing, Anna (2015): The Mushroom at the End of the World: On the possibility of Life in Capitalist Ruins. Princeton: Princeton University Press.

Van Maanen, John (2011 [1988]): Tales of the field: On writing ethnography. London: University of Chicago Press.
Viveiros De Castro, Eduardo (1998): Cosmological Deixis and Amerindian Perspectivism. Journal of the Royal Anthropological Institute, 4(3), 469488

Wiede, Lawrence (1980): Behavioristic operationalism and the lifeworld: Chimpanzees and chimpanzee researchers in face-to-face interaction. Sociological Inquiry 50, 75-10.

Wolh, Hellen (2019): Saving the Dammed: Why We Need Beaver-Modified Ecosystems. Oxford: Oxford University Press.

\section{AUTHOR}

Paride Bollettin is $\mathrm{PhD}$ in Anthropology by the University of Siena and works with Amerindian Mebengokré people since 2005. Actually he is Assistant Professor at the Department of Anthropology, Faculty of Science, Masaryk University.

Contact: paride_bollettin@msn.com 
